EUROPA REGIONUM TOM XXIII ROK 2015

DOI: $10.18276 /$ er.2015.23-09

BOGUSŁAW STANKIEWICZ

Zachodniopomorski Uniwersytet Technologiczny w Szczecinie

\title{
Przed ćwierćwieczem polskiej agroturystyki \\ - glosa do jubileuszowej publikacji \\ profesor Jolanty Wojciechowskiej
}

\section{Wprowadzenie}

$\mathrm{N}$

a 2015 rok przypadnie jubileusz 25-lecia funkcjonowania polskiej agroturystyki, przy czym jako cezurę czasową przyjmuje się 1991 rok, czyli moment utworzenia Polskiej Izby Agroturystyki i Turystyki, którą to datę symbolicznie wyeksponowała J. Wojciechowska poświęcając temu wydarzeniu okolicznościową publikację (Wojciechowska 2011).

Nie ulega najmniejszej wątpliwości, iż Autorka wspomnianego artykułu na co dzień pracownik naukowy w Uniwersytecie Łódzkim - jest znakomitą znawczynią problematyki agroturystyki (agroturyzmu) i opiniotwórczą uczoną, o czym świadczy nie tylko Jej dorobek naukowy, ale także fakt, iż mimo upływu 4 lat od daty przytoczonej publikacji, zawarte tam opinie, tezy i pytania nie straciły aktualności i nadal mogą być przedmiotem ożywionej dyskusji. Przykładowo można wymienić takie kompleksy zagadnień poruszonych przez J. Wojciechowska, jak:

- multidyscyplinarny charakter agroturystyki i jej miejsce w systemie turystyki,

- kierunki rozwoju agroturystyki w Polsce - od rozwoju egzogenicznego do rozwoju endogenicznego,

- strategie badawcze, a w tym: trudności w pozyskaniu danych faktualnych, ograniczony (wycinkowy) charakter badań, brak kompatybilności wyników badań nad agroturystyką w Polsce i rozproszenie wysiłku badawczego, 
- integracja pozioma i pionowa agroturystyki w Polsce oraz modele rozwoju polskiego agroturyzmu.

Biorąc pod uwagę rozległość, złożoność oraz ważkość każdego z zasygnalizowanych tematów (zagadnień) celem niniejszego artykułu nie jest krytyczne (negujące) ustosunkowanie się do poglądów i koncepcji Profesor J. Wojciechowskiej, lecz próba skomentowania, z konieczności wybranych wycinków funkcjonowania agroturystyki, przez pryzmat wiedzy skumulowanej w naukach ekonomicznych i naukach o turystyce, co zamierzamy uczynić.

\section{Agroturystyka a inne nauki - konceptualizacja problemu \\ 1.1. Warunki brzegowe}

Przyjęcie założenia o szczególnym charakterze agroturystyki rodzi naszym zdaniem dwie konsekwencje (alternatywę):

1) agroturystyka jest subdomenq turystyki, która jest przedmiotem badań wielu dyscyplin: od nauk o rolnictwie, przez filozofie, nauki ekonomiczne, socjologie, psychologię, nauki prawne, regionalistyke, planowanie przestrzenne po historię i historię gospodarczą etc. (i tu zgoda);

2) agroturyzm stał się samodzielną dyscypliną naukową integrującą inne naukito jest rezonans twierdzeń wielu badaczy, iż turystyka (ekonomika turystyki) jako element składowy nauk ekonomicznych wyzbyła się kompleksów i stała się interdyscyplinarnym kierunkiem nauki obejmujaccym podstawy teoretyczne i wiedzę w przedmiocie turystyki (przykładowo opinie: L. Dwyera, P. Forsytha i W. Dwyera 2010, M.J. Stablera i zespołu 2010, J. Tribe'go 2011) (i tu powstają wątpliwości).

Akceptacja pierwszego rozwiązania nie oznacza wyzbycia się szeregu wątpliwości odnośnie efektów koordynacji badań w ramach wielu samodzielnych dyscyplin naukowych, z których każda posługuje się inną typologią zjawisk, innymi definicjami tych samych pojęć i różnymi metodami badawczymi. Jak to trafnie ujął D. Cormany (2013) strategia badań z udziałem wielu dyscyplin winna dać odpowiedź na nastepujące pytania:

- jaki jest na rok 2015 stan wiedzy o agroturystyce?

- czy istnieją różnice w ramach poszczególnych nauk odnośnie typologii, definicji i pojęć w agroturystyce?

- czy widoczna jest dominacja którejś z nauk w objaśnianiu agroturyzmu? 
- czy i na jakich badaniach oparte są wnioski i uogólnienia z różnych nauk uważane za powszechnie obowiązujące?

W opinii wielu badaczy agroturystyka jest fenomenem zachowań turystycznych na przełomie XX i XXI wieków oraz w latach bieżących XXI w - pogląd ten wyznaje także J. Wojciechowska (2011). Stanowisko to wydaje się mieć charakter bardziej marketingowy niż faktyczny - należy zgodzić się, iż spośród subdomen turystyki fenomenem w porównywalnym okresie jest turystyka medyczna. Świadczą o tym (nawet przy relatywnej szczupłości twardych danych HD) takie parametry jak: w makroskali - wpływ na wzrost gospodarczy (PKB) oraz wielkość i tempo wzrostu medical tourism, w skali mikro: innowacyjność i standing ekonomiczny przedsiębiorstw tejże subdomeny i tego polskiej agroturystyce należy życzyć.

Wypada zgodzić się natomiast z konkluzjami tych badaczy, którzy twierdzą, iż agroturyzm jako nowe jakościowo zjawisko w turystyce jest szczególnym podzbiorem szerszego zbioru turystyki na obszarach wiejskich (Clarke 1999). Fakt ten potwierdza także, wcześniejsza czasowo, definicja agroturystyki autorstwa OECD (1994).

\subsection{Agroturystyka w trójkącie: rolnictwo, ekonomia, turystyka - implikacje badawcze}

Nie ma potrzeby odwoływania się do przykładów definicji agroturystyki aby mieć pewność, iż jej przestrzeń funkcjonowania jako zjawiska mieści się między Scyllą rolnictwa (jako działu gospodarki narodowej) a Charybdą turystyki (innego działu), wszakże większość definicji agroturystyki, także typologii - jak słusznie podkreśla J. Wojciechowska - odwołuje się do związków (zależności) między tymi dwoma typami gospodarowania. Istnieje jednak, $\mathrm{z}$ coraz częstszym prawem obywatelstwa, moderator relacji wzajemnych rolnictwoagroturyzm, a jest nim ekonomia (plus towarzyszące działalności gospodarczej procesy społeczne), a wężej prawa rynku i konkurencyjność rynkowa.

O fakcie rozluźniania się związków między rolnictwem a agroturystyką istnieje w literaturze przedmiotu wiele doniesień i wniosków, z których do najważniejszych należy zaliczyć:

1) W 2006 r. G. Busby i S. Rendl stwierdzili, iż związki miedzy agroturystyką i rolnictwem są coraz słabsze. Okazało się, że rolnicy, którzy potraktowali agroturystykę jako alternatywne źródło dochodu swoich gospo- 
darstw, powoli rozstawali się z rolniczą działalnością gospodarczą. Innymi słowy aktywna działalność rolnicza nie jest już niezbędnym elementem agroturystyki (Busby, Rendle 2006). Podobne procesy mają miejsce także w Polsce,

2) w tymże samym roku dwaj niemieccy badacze A. Fleischer i A. Tchetchik wykazali, iż agroturyści są skłonni uiścić nawet wyższą, od proponowanej, cenę za pobyt, jeśli w rejonie zamieszkania (destynacji agroturystycznej) występuje bogactwo innych atrakcji turystycznych. Ponadto stwierdzili oni - i to ma ekonomicznie doniosłe skutki - iż firmy (przedsiębiorstwa) agroturystyczne usytuowane w takim rejonie osiagają wyższą wydajność (rentowność) w porównaniu do konkurencji rozlokowanej na innych (czyli pozbawionych atrakcji) obszarach (Fleischer, Tchetchik 2006),

3) Również w 2006 r. E. Parra Lopez i F.J. Calero Garcia badając uwarunkowania agroturystyki i zrównoważonej turystyki na Wyspach Kanaryjskich podnieśli, iż agroturystyka może być źródłem negatywnych, praktycznie nieodwracalnych, zmian w krajobrazie. (Para Lopez, Calero Garcia 2006). Stanowi to, nawet nienazwany wprost, dowód, iż także agroturystyka może być katalizatorem tzw. choroby holenderskiej, który to termin wprowadził do obiegu naukowego w 1991 r. B.R. Copeland (1991).

Niezależnie od skutków „ekonomizacji” agroturystyki nieodzowną staje się uwaga o wpływie teorii i szkół istniejących poza tzw. ekonomią głównego nurtu na stan badań nad agroturystyką i zasadnicze akcenty (układy odniesienia) tychże badań. O ile w agroturystyce, także polskiej, widoczna jest dyfuzja myśli ekonomii zrównoważonego rozwoju, ekoekonomii, także ekonomii behawioralnej, to agroturyzm (podobnie jak ekonomika turystyki) jeszcze opiera się wpływom szkoły zasobów (RBV). Paradoks polega na istnieniu sytuacji, w ramach której praktycznie cały sektor bazuje na zasobach własnych widzianych w optyce VRIN (zasoby cenne, rzadkie, niepowtarzalne i trudne do imitacji) autorstwa Jaya B. Barneya (1994).

Rozwój sektora agroturystycznego (natężenie procesów konkurowania) w Polsce wskazuje na obiektywne zapotrzebowanie na wiedzę nie tylko o czynnikach na wejściu i na wyjściu przedsiębiorstwa (firmy, gospodarstwa agroturystycznego), ale także o jego wnętrzu, czyli otwiera drogę do kombinacji (rekombinacji) elementami zasobów niezbędnych w procesie konkurowania, a więc: kompetencji, kluczowych kompetencji, możliwości i dynamicznych możliwości 
oraz ich wdrażania (Peteraf, Barney 2003, Makadok 2001, Eisenhardt, Martin 2000).

J. Wojciechowska słusznie wskazuje na potrzebę intensyfikacji badawczej nad kondycją agroturystyki w Polsce, a za kryterium oceny perspektywicznej uznaje standaryzację badań. Przyznając zasadność i racjonalność koncepcji mieszczącej się w nucie multidyscyplinarnym, kierując się wiedzą z dziedziny nauk ekonomicznych opracowano autorską koncepcję najważniejszych badań, co przedstawiono w tabeli 1 .

Tabela 1

Kierunki badań ekonomicznych agroturystyki w Polsce

\begin{tabular}{|c|c|}
\hline $\begin{array}{c}\text { Układ } \\
\text { odniesienia }\end{array}$ & Proponowana tematyka \\
\hline Poziom makro & $\begin{array}{l}\text { - podejmowanie decyzji o alokacji i wykorzystaniu zasobów agroturystyki, } \\
\text { konsekwencje publiczne, społeczne i polityczne wykorzystania zasobów } \\
\text { - kompromisy zasobowe, wydajność ekonomiczna i społeczna agroturystyki, } \\
\text { normy kulturowe, optymalizacja połączenia zasobów agroturystyki i innych } \\
\text { działów gospodarki narodowej (relacje międzydziałowe), skala i ekonomia } \\
\text { wielkości (rozkłady wielkości, pozioma i pionowa integracja } \\
\text { przedsiębiorstw agroturystycznych) } \\
\text { - skutki ekonomiczne i społeczne wprowadzania innowacji i zmian } \\
\text { instytucjonalnych w agroturystyce (wykorzystanie zasobów, zmiany pro- } \\
\text { duktowe agroturystyki, transfer technologii, e-technologie w agroturystyce) }\end{array}$ \\
\hline Poziom mikro & $\begin{array}{l}\text { - gospodarstwa agroturystyczne jako przedsiębiorstwa (biznes, ekonomia } \\
\text { przedsiębiorstwa agroturystycznego, ekonomika gospodarstwa domowego } \\
\text { przedsiębiorcy agroturystycznego, małe, średnie i duże przedsiębiorstwa } \\
\text { agroturystyczne) } \\
\text { - korekty wykorzystania zasobów na poziomie indywidualnego gospodarstwa } \\
\text { agroturystycznego, obszaru, regionu (energia, kapitał pracy, skala produkcji, } \\
\text { dochód z agroturystyki) } \\
\text { - praca gospodarstw (farm agroturystycznych) - zasilanie, ryzyko i bezpie- } \\
\text { czeństwo, wydajność, wiedza i szkolenia, skomputeryzowane systemy } \\
\text { ewidencji i przetwarzania danych, modele planowania finansowego, } \\
\text { systemy zarządzania przedsiębiorstwem agroturystycznym (finansowe } \\
\text { systemy zarządzania, księgowość i budżetowanie gospodarstw, zarządzanie } \\
\text { inwestycjami, zarządzanie zasobami własnymi) } \\
\text { - innowacyjność i konkurencyjność przedsiębiorstwa agroturystycznego } \\
\text { (kombinacja i rekombinacja zasobów) } \\
\text { - łańcuch wartości przedsiębiorstwa agroturystycznego, oligopole i alianse } \\
\text { strategiczne w agroturystyce }\end{array}$ \\
\hline
\end{tabular}

Źródło: opracowanie własne na podstawie studiów literaturowych. 


\section{Modele, modelowanie i pomiar procesów w agroturystyce}

Modelowanie procesów gospodarczych ma w nauce (w naukach ekonomicznych oraz w innych dyscyplinach) długą tradycję i ogromne zasoby wiedzy, których analiza upoważnia do wyodrębnienia dwóch zasadniczych typów modeli:

- modele zarządzania procesami gospodarczymi,

- modele rozwojowe procesów gospodarczych.

Jest to o tyle istotne, gdyż jak wspomniano wcześniej, agroturystyka znajduje się w swoistym napięciu między obserwacją, diagnozą i naukowym uogólnieniem procesów gospodarowania w rolnictwie a analogicznymi tendencjami mającymi miejsce w turystyce.

Jak słusznie zauważył zespół G. Huylenbroecka, celem integrującym rolnictwo i turystykę na obszarach wiejskich winno być synergiczne wykorzystanie propytowych czynników w obu rodzajach działalności z myślą o ciagłym wzroście i poprawie efektywności funkcjonowania rolnictwa i turystyki (Huylenbroeck i zespół 2006). I w tym miejscu powstają dwie uwagi szczegółowe:

a) J. Wojciechowska wymieniła i scharakteryzowała najważniejsze polskie dokonania w przedmiocie konstrukcji teoretycznych modeli agroturystyki, a odczytanie Jej opinii prowadzi do konstatacji, iż jest zwolenniczką modelowania zarządzaniem agroturystyką z myślą o przyszłości (Future);

b) znawcy problematyki zarządzania rolnictwem doskonale wiedzą, iż praktycznie wszystkie współczesne modele zarządzania tym działem mają amerykański rodowód. Swego czasu ogromny rezonans wywarły ustalenia zespołu młodych badaczy australijskich, których kwintesencja jest następująca: w modelach zarządzania rolnictwem jest wszystko, ale nie ma teorii ekonomii! (McCrown i zespół 2006a, 2006b). I tego, powtórzmy za Australijczykami, „historycznego niepowodzenia” (historical failure) w tworzeniu modeli rozwojowych agroturystyki w Polsce należy się wystrzegać.

Nie widzimy potrzeby uzasadniania, istniejącego w zasobach wiedzy i znanego badaczom polskim, postępowania niezbędnego przy tworzeniu teoretycznych modeli agroturystyki, którego najważniejsze etapy to:

a) etap I: porządkowanie przestrzeni badawczej, typologia, standaryzacja pojęć i terminów; 
b) etap II: wybór i konstrukcja samego modelu (zmienne objaśniane, wykorzystanie danych, wybór metody badawczej - badania jakościowe lub ilościowe) i przeprowadzenie badania;

c) etap III: testowanie (weryfikacja) ustaleń badawczych;

d) etap IV: wnioskowanie, tworzenie teorematów natury ogólniejszej.

$\mathrm{Na}$ etapie pierwszym pomocną może być 5-elementowa typologia agroturystyki zaproponowana przez zespół badaczy brytyjskich, co dostrzegła J. Wojciechowska (2011, przypis 15). Wspomniana koncepcja ma walor uniwersalności i, co najważniejsze, jej przypadki mają swoje odniesienie na gruncie rzeczywistości polskiej (Phillip i zespół 2010).

$\mathrm{Na}$ etapie drugim ważnym zagadnieniem wydaje się być sam wybór modelu wyjściowego, który ma stać się układem odniesienia przy konstrukcji nowych modeli agroturystyki. Już w 1986 r., a więc przed oficjalnymi narodzinami agroturystyki w Polsce, K.M. Haywood (1986), potwierdził operacyjną przydatność (czyli zgodność z celami marketingowymi tworzenia produktów turystycznych) tzw. cyklu życia kurortu autorstwa R.W. Butlera (1980), a w 1989 r. C. Cooper i S. Jackson zaproponowali wspomniany cykl jako podstawę tworzenia modeli rozwojowych agroturystyki (1989). Problemem do przezwyciężenia przy konstrukcji modelu prognozowania jest dostępność danych oraz tworzenie liniowych modeli wielomianowych. Jak łatwo zauważyć, budowa modeli winna przebiegać z udziałem systemu regresji liniowej, a także - co ma miejsce przy konstruowaniu modeli rozwojowych turystyki - znacznie bardziej wyrafinowanych narzędzi matematyczno-statystycznych (ekonometrycznych).

Niezwykle istotny jest etap trzeci - tu w oparciu o wyniki statystyczne, sprawdzenie i ocenę przydatności danych zapada decyzja o wyborze modelu końcowego (finalnego). Wymaga to przezwyciężenia takich szczegółowych problemów, jak: kontrola korelacji reszt, opóźnienia czasowe zmiennej zależnej itd. Kolejnym zagadnieniem staje się wybór narzędzi testowania. Nie wgłębiając się w detale wspomnimy jedynie, iż przy mniej wyrafinowanych modelach zastosowanie mogą mieć:

- test dystrybucji t (t-Test),

- test dystrybucji F (f-Test),

- statystyka Durbina-Watsona (D-W),

- badanie autokorelacji (AR),

- badanie warunkowe heteroskedastyczności (ARCH),

- test normalności (NORM), 
- test postaci funkcjonalnego modelu (RESET) oraz

- test heteroskedastyczności (Heter).

Reasumując, postęp wiedzy o agroturystyce dziś i jutro to wypadkowa dwóch procesów: obiektywnego postępu w sektorze oraz zaangażowania badawczego zainteresowanych środowisk akademickich.

\section{Zamiast podsumowania}

Heterogeniczność agroturystyki jest faktem, podobnie jej procesy rozwojowe - jak i procesy w innych działach gospodarki - odbywają się we współzależności $\mathrm{z}$ otoczeniem zewnętrznym. Można więc $\mathrm{w}$ ogólnym sensie mówić o upodobnianiu się agroturystyki i jej ogniw składowych (przedsiębiorstw) do przemysłu, a tzw. szczególna rola tej formy turystyki stopniowo traci na wyrazistości.

Z drugiej strony agroturystyka ma jeszcze do odrobienia pewien dystans dzielący ją zarówno od rolnictwa, jak też od turystyki sensu largo. Ilustracją oczekiwanego (postulowanego) postępu jest porównawcze zestawienie dwóch ogólnych parametrów, jakże istotnych w procesie badawczym, które przedstawiono w tabeli 2 . Komentarz i wnioskowanie pozostawiamy zainteresowanym.

Tabela 2

Rolnictwo, turystyka i agroturystyka - wybrane elementy procesu badań

\begin{tabular}{|c|l|l|l|}
\hline Element & \multicolumn{1}{|c|}{ Rolnictwo } & \multicolumn{1}{|c|}{ Ekonomika turystyki } & Agroturystyka \\
\hline $\begin{array}{l}\text { Hipoteza } \\
\text { badawcza }\end{array}$ & brak & $\begin{array}{l}\text { 1.TLG (the tourism-led-growth hypoth- } \\
\text { esis) } \\
\text { 2.TCGI (tourism capital good import } \\
\text { hypothesis) } \\
\text { (Schubert i inni 2011, Nowak i inni } \\
\text { 2007). }\end{array}$ & \\
\hline $\begin{array}{l}\text { Metody } \\
\text { badawcze }\end{array}$ & $\begin{array}{l}\text { Stosowanie wyrafinowanych } \\
\text { metod badawczych - modyfi- } \\
\text { kacja łączenia sieci neurono- } \\
\text { wych i rachunku wsparcia } \\
\text { wektorowego oparta na opty- } \\
\text { malizacji roju cząstek. (Quin- } \\
\text { gyu Zhou 2011) }\end{array}$ & $\begin{array}{l}\text { 1. Integracja zmiennych w czasie para- } \\
\text { metrów z przyczynowym typoszere- } \\
\text { giem czasowym } \\
\text { 2. Metoda korekcji błędów kointegracji } \\
\text { 3. Wektor autoregresji (VAR), (Cang } \\
\text { 2011) }\end{array}$ & punkcie 2 \\
\hline
\end{tabular}

Źródło: opracowanie własne na podstawie literatury zamieszczonej w tabeli oraz studiów literaturowych. 


\section{Bibliografia}

Barney J.B. (1994), Bringing Managers Back In: A Resource-Based Analysis of the Role of Managers in Creating and Sustaining Competitive Advantages for Firms, Does management matter? On competencies and competitive advantage, The 1994 Crafoord lectures, s. 1-36.

Busby G., Rendle S. (2006), The transition from tourism on farms to farm tourism, Tourism Management, 21 (6), s. 635-642.

Butler R.W. (1980), The concept of a tourist area life cycle of evolution, Canadian Geographer, 24, s. 5-12.

Cang S. (2011), A non-linear tourism demand forecast combination model, Tourism Economics, 17 (1), s. 5-20.

Clarke, J. (1999), Marketing structures for farm tourism: beyond the individual provider of rural tourism, Journal of Sustainable Tourism, 7, s. 26-47.

Cooper C.S., Jackson S. (1989), Destination life cycle. The Isle of Main case study, Annals of Tourism Research, 16, s. 377-398.

Copeland B.R. (1991), Tourism, welfare and de-industrialization in a small open economy, Economica, 58 (232), s. 515-529.

Cormany D. (2013), Motives for Different Types of Medical Travelers: An Analysis of the Current State of Academic Research on the Topic, University of Nevada, Las Vegas.

Dwyer L., Forsyth P., Dwyer W. (2010), Tourism Economics and Policy, Channel View Publications, Bristol UK.

Eisenhardt K.M., Martin J.A. (2000), Dynamic Capabilities: What are They?, Strategic Management Journal, 21, s. 1105-1121.

Fleischer A., Tchetchik A. (2006), Does rural tourism benefit from agriculture?, Tourism Management, 26, s. 493-501.

Haywood K.M. (1986), Can the tourist-area life cycle; An application to the tourist product, Tourist Management, 7, s. 154-167.

Huylenbroeck G., Vanslembrouck I., Calus M., Velde L. (2006), Synergies between Farming and Rural Tourism: Evidence from Flanders, EuroChoices, 5 (1) s. 14-21.

Makadok R. (2001), Towards a Synthesis of Resource-Based and Dynamic Capability Views of Rent Creation, Strategic Management Journal, 22, s. 387-402.

McCrown R.L., Brennan L.E., Parton K.A. (2006a), Learning from the historical failure of farm management models to aid management practice. Part 1. The rise and demise of theoretical models of farm economics, Australian Journal of Agricultural Research, 57, s. 143-156,

McCrown R.L., Brennan L.E., Parton K.A., (2006b), Learning from the historical failure of farm management models to aid management practice. Part II. Three Systems Approaches, Australian Journal of Agricultural Research, 57, s. 157-172.

Nowak J., Sahli M., Cortes-Jimenez I. (2007), Tourism, capital good imports and economic growth: theory and evidence for Spain, Tourism Economics, 13 (4), s. 515-536,

OECD (1994), Tourism Strategies and Rural Development, Paris, dostęny na stronie internetowej: http://www.oecd.org/dsti/sti/transpor/tourism/prod/e-94-49.pdf. 
Para Lopez E., Calero Garcia F.J. (2006), Agrotourism, sustainable tourism and Ultraperipheral areas:The Case of Canary Islands, Revista de Turismo y Patrimonio Cultural, 4 (1), s. 85-97.

Peteraf M.A., Barney J.B. (2003), Unraveling the Resource-Based Tangle, Managerial and Decision Economics, 24, s. 309-323.

Phillip S., Hunter C., Blackstock K. (2010), A typology for defining agritourism, Tourism Management, 31, s. 754-758.

Quingyu Z., Jing L., Feng X., Quingchao L. (2011), The Method Research on Optimum Selection of Agricultural Machinery, International Journal of Digital Content Technology and its Applications, 5 (6), s. 337-344.

Schubert S.F., Brida J.G., Risso W.A. (2011), The impacts of international tourism demand on economic growth of small economies dependent on tourism, Tourism Management, 32, s. 377-385.

Stabler M.J., Papatheodorou A., Sinclair M. (2010), The Economics of Tourism, wydanie drugie, Routledge, Abingdon UK.

Tribe J. (2011), The Economics of Recreation, Leisure \& Tourism, ButterworthHeinemann, Oxford UK.

Wojciechowska J. (2011), Twenty years of polish agritourism: the past and the future, Tourism, 21 (1-2).

\section{Before the quater of a century of polish agrotourism \\ - gloss to the jubilee publication of \\ Professor Jolanta Wojciechowska}

Article is a form of duo over the condition of the state of agro tourism in Poland as seen from the economist perspective, deliberately referring with some time distance, to the commemorative publication of Professor Jolanta Wojciechowska. The concept of selective choice of research matter was adopted - it is primarily the character of the agro tourism as a field of science and its place in the triangle: agriculture; economics of tourism, agro tourism and agro tourism modeling for the future purposes. In the article author has proposed set of the most significant topics in macro and micro scale (of the agritourism company) from the economics view. In the conclusion part was made a comparative analysis of research strategies of the economics of tourism, agro tourism and agriculture on the basis of the literature study. 